\title{
Effects of a Low-Head Dam Removal on River Morphology and Riparian Vegetation: A Case Study of Gongreung River
}

\author{
Si Nae Kim*, Yuji Toda, Tetsuro Tsujimoto \\ Department of Civil Engineering, Nagoya University, Nagoya, Japan \\ Email: flowerksn@hotmail.com
}

Received 19 September 2014; revised 16 October 2014; accepted 11 November 2014

Copyright (C) 2014 by authors and Scientific Research Publishing Inc.

This work is licensed under the Creative Commons Attribution International License (CC BY).

http://creativecommons.org/licenses/by/4.0/

cC) (7) Open Access

\begin{abstract}
The long term existence of a low-head dam in the river channel significantly affects river geomorphology and river ecosystem. Because more and more low-head dam structures have deteriorated in recent years, the attention for low-head dam removal is increasing as one of alternatives for river restoration. Thus, this study intends to investigate the impacts of low-head dam removal on river geomorphology and riparian vegetation with developing a quantitative method to predict the changes of river morphology as well as invasion, growth, expansion and destruction of riparian vegetation after a low-head dam removal. To verify the numerical simulation model, the lowhead dam removal case in Gongreung River was employed with investigation of low-head dam removal responses on river geomorphology and riparian vegetation. Following the low-head dam removal, the results of monitoring and numerical simulation indicated that new sand bars has formed as well as increasing the extent of existing sand bars in the upstream of the low-head dam. The sand bars have been colonized in a year after the low-head dam removal by grass type plants. After a decade to several decades, the riparian vegetation in sand bars often developed to tree type plants in several low-head dam removal cases. As other cases, Gongreung River also showed the growth of tree type plants in 5 years after the removal.
\end{abstract}

\section{Keywords}

Low-Head Dam Removal, River Morphology, Riparian Vegetation, Numerical Simulation

\section{Introduction}

In recent years, the number of deteriorated low-head dam structures is drastically increasing due to their life

\footnotetext{
${ }^{*}$ Corresponding author.
}

How to cite this paper: Kim, S.N., Toda, Y. and Tsujimoto, T. (2014) Effects of a Low-Head Dam Removal on River Morphology and Riparian Vegetation: A Case Study of Gongreung River. Journal of Water Resource and Protection, 6, 1682-1690. 
span ranging about 50 years. Particularly, numerous existing low-head dams which were constructed between 1970s and 1980s are expected to be deteriorated in the next decade. Many deteriorated dams which were abandoned in the river channel cause serious problem for river ecosystem and flood safety. To improve river ecosystem, low-head dam removal is emerging as an alternative for river restoration.

Previous studies on a low-head dam removal documented that significant changes have been observed on river morphology and riparian vegetation following a low-head dam removal. Especially, the channel evolution by transporting stored sediment in upstream of a low-head dam greatly alters river channel exposing large bare ground and often creating floodplains. The stored sediment often forms a knick point or head cut in the river channel as soon as a low-head dam removed. Doyle et al., 2005 [1] found that the migration of head cut controls subsequent channel development in upstream of a low-head dam. The intensity of a head cut migration to channel evolution is mostly depends on the character of deposited sediment. Layered or cohesive deposits have been shown to produce stepped knick point or head cut following dam removal [2] resulting in channel incision, widening by bank failure, and building floodplains [3] [4].

These morphological changes create suitable surface for riparian vegetation [5]. Orr and Stanley, 2006 [6] mentioned that all dam removal sites had extensive vegetation cover and sites retain high cover of vegetation based on 30 dam removal sites in Wisconsin. Also, they found that the growth of tree plants is considerably related to time since dam removal. While a lot of low-head dam removals are expected in near future, only few studies take note of the responses on low-head dam removal. With insufficient monitoring data on pre and post removal and researches, the impacts on river geomorphology and riparian vegetation by the low-head dam removal have not been quantified.

Thus, it is necessary to develop a quantitative method to predict the low-head dam removal responses on river morphology with riparian vegetation development for river management. To develop a quantitative method, this study intends to 1) investigate a low-head dam removal impacts with the monitoring results of Gongreung 2 dam removal; and 2) develop a numerical simulation model for river morphology and riparian vegetation changes following a low-head dam removal with verification by the case of Gongreung River.

\section{Study Area}

Gongreung River is a tributary of Han River located in Goyang-si, Gyenggi province, Korea (Figure 1). The river is $45.7 \mathrm{~km}$ in length and $253.1 \mathrm{~km}^{2}$ in area of watershed with $1 / 200$ of average bed slope. The mean annual precipitation of the watershed is $1384 \mathrm{~mm}$ with the maximum and minimum were $2355.5 \mathrm{~mm}$ in 1990 and 760.8 $\mathrm{mm}$ in 1988 respectively.

Gongreung 2 dam is a low-head dam for the purpose of agriculture irrigation constructed in 1970s. The lowhead dam was a $76 \mathrm{~m}$ wide and $1.5 \mathrm{~m}$ high concrete dam structure. The low-head dam was removed in April, 2006 because it lost the function for irrigation by land use changes of surrounding agricultural area and excessive sediment deposition in the reservoir (Figure 2). Another low-head dam in the $600 \mathrm{~m}$ downstream side from the Gongreung 2 dam is still in existence.

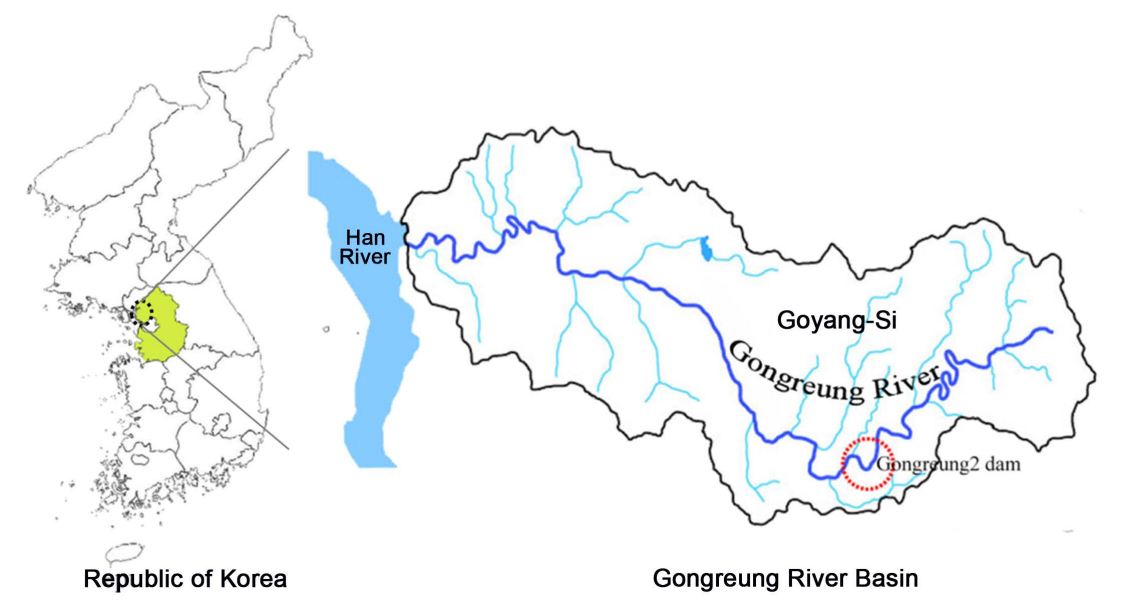

Figure 1. Gongreung River in Republic of Korea. 

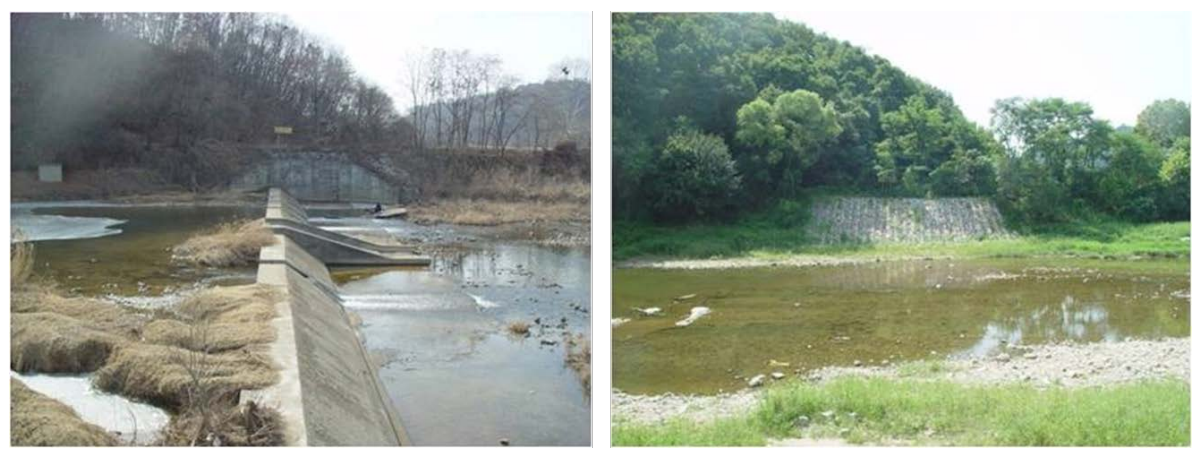

Figure 2. Gongreung 2 dam before (left) and after (right) the dam removal.

\section{Low-head Dam Removal Monitoring}

\subsection{Methods}

To analyze the low-head dam removal effects, monitoring has performed for river morphology and riparian vegetation on $1 \mathrm{~km}$ section from $400 \mathrm{~m}$ far upstream to $600 \mathrm{~m}$ far downstream of the Gongreung $2 \mathrm{dam}$. The field measurement for morphological changes had performed in before removal on April 1, 2006, just after removal on May 30, after floods on August 4, 2006, and November 1, 2007. To analyze the morphological impacts, cross section of river, river bed elevation and sediment characteristics were observed. The monitoring of riparian vegetation performed in March 2006 before removal, November 2006, and May 2007 after removal.

\subsection{River Morphology}

The reservoir in upstream of the low-head dam was accumulated with fine sediment as high as the height of the dam structure. To prevent drastic downstream impacts by excessive sediment transport, some of the accumulated reservoir sediment was artificially dredged during the low-head dam removal construction.

On river morphological changes following a low-head dam removal, a headcut migration is a common and critical phenomenon of the upstream channel evolution, and a headcut migration is governed by the characteristics of accumulated sediment in the reservoir [3] [4]. In Gongreung 2 dam removal, monitoring results of riverbed cross section showed that a headcut migration started after removal moving toward $25 \mathrm{~m}$ upstream in 2 months. However, the morphological impacts by the headcut migration have not significantly affected the channel evolution in case of Gongreung 2 dam removal, because the accumulated sediment was dredged before the removal construction.

Following the low-head dam removal, the river bed elevation in upstream has degraded $0.67 \mathrm{~m}$ and $0.84 \mathrm{~m}$ at $10.93 \mathrm{~m}$ upstream point from the dam and the point of previous dam, respectively. In downstream, the river bed elevation has aggraded $0.52 \mathrm{~m}$ and $0.27 \mathrm{~m}$ at the point of $22.70 \mathrm{~m}$ and $39.68 \mathrm{~m}$ downstream side, respectively (Figure 3). However, farther downstream has no significant change of river bed elevation due to the impacts by another low-head dam existence located in $600 \mathrm{~m}$ downstream side from the removed low-head dam.

Moreover, the number and size of sand bars have subsequently increased in upstream of the low-head dam. The transported sediment from upstream reservoir also increased the size of sand bars in downstream of the lowhead dam. These changes contribute to velocity distribution to be various improving diversity of flow structures such as pool and riffle.

The sediment both upstream and downstream has coarsened following the low-head dam removal. In upstream of the low-head dam, the median grain size has coarsened from $0.51 \mathrm{~mm}$ before removal to $1.96 \mathrm{~mm}$ after removal exposing underlying coarse sand in the reservoir. The median grain size in downstream of the lowhead dam also became coarser from $2.74 \mathrm{~mm}$ before removal to $10.73 \mathrm{~mm}$ after removal exporting large amount of fine sediment by flood in July 2006.

\subsection{Riparian Vegetation}

Following the low-head dam removal, the number of riparian vegetation species in upstream of the low-head dam drastically increased from 32 species before removal (March 2006) to 54 species in November 2006 and 67 


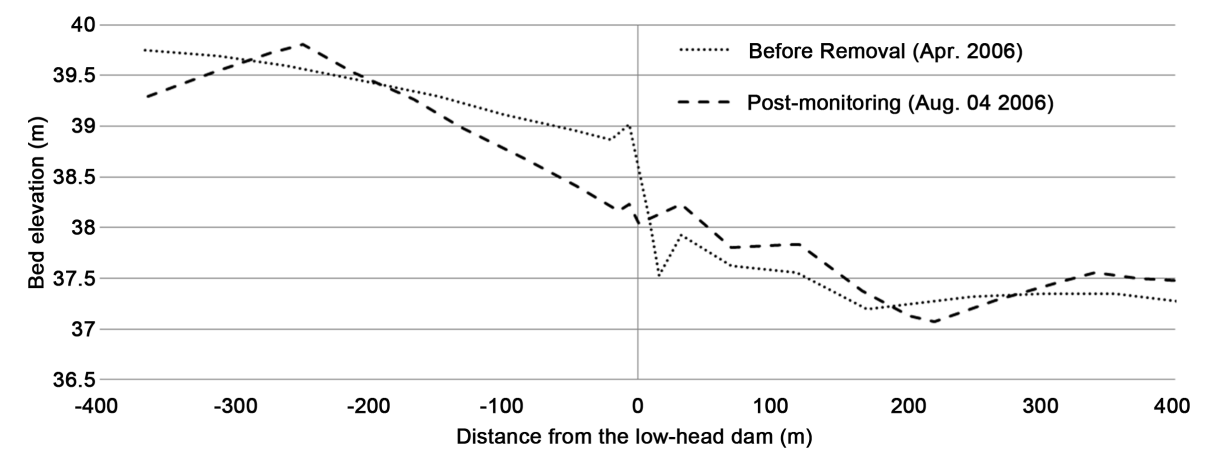

Figure 3. Monitoring results of river bed elevation changes.

species in May 2007 after removal. Because the low-head dam removal exposed the deposited sediment in the previous impoundment, new vegetation could be settled in the bare ground. In downstream of the low-head dam, 41 species before removal (March 2006), 61 species in November 2006, and 52 species in May 2007 were observed.

The percentages of pioneer species were more than $50 \%$ of total vegetation species in both upstream and downstream of the low-head dam. The dominance of pioneer species indicates that significant morphological changes by low-head dam removal disturbed and changed the physical habitat conditions for riparian vegetation.

The area of vegetation has increased following the low-head dam removal with the formation of large sand bars in upstream and increasing the size of sand bars in downstream (Figure 4). Because the left bank of upstream is a rock mountain with steep slope, most sand bars and riparian vegetation developed in the right bank side.

\section{Numerical Simulation}

\subsection{Numerical Simulation Model}

To analyze the post low-head dam removal impacts, the numerical simulation model has developed with the calculation of flow, sediment transport and riparian vegetation in flood and ordinary water stage. Input data are initial morphology, sediment diameter and discharge. In flood stage, the simulation model calculates the flow and bed load transport as well as the destruction of riparian vegetation by flood. The invasion, growth and expansion of riparian vegetation are designed to calculate in ordinary water stage (Figure 5).

\subsubsection{Flow Calculation}

In order to simulate flow in flood stage, shallow water equation was employed to calculate the water depth and depth-averaged flow velocity. Using Manning's resistance law, the bottom friction and drag force of riparian vegetation are calculated. In terms of sediment transport in flood stage, the bed load transport in lateral and longitudinal direction is calculated with the MPM equation [7] and Hasegawa equation [8], respectively.

\subsubsection{Growth and Expansion of Riparian Vegetation}

The growth and expansion of riparian vegetation are calculated in ordinary water stage. To simulate the vegetation dynamics, this numerical simulation model sorts the riparian vegetation into grass type and tree type plants briefly. For the interspecific competition of riparian vegetation, it is assumed that the higher vegetation can take more light for photosynthesis. The growth of both types of riparian vegetation is calculated by the balance of primary production and respiration [9]. The horizontal expansion of riparian vegetation is formulated by diffusion type formula in the growth equation. The equation for growth of the riparian vegetation is given by:

$$
\frac{\partial M_{i}}{\partial t}=P_{i}-R_{i}+\frac{\partial}{\partial x}\left(k_{x i} \frac{\partial M_{i}}{\partial x}\right)+\frac{\partial}{\partial y}\left(k_{y i} \frac{\partial M_{i}}{\partial y}\right)
$$

in which $M_{i}$ : biomass per unit area, $P_{i}$ : primary production, $R_{i}$ : respiration, $K_{x i}, K_{y i}$ : the diffusion coefficients for horizontal expansion of vegetation in $x$ and $y$ directions, respectively. The subscript $i$ denotes the index identifying the grass $(g)$ and tree $(t)$ types of vegetation. 


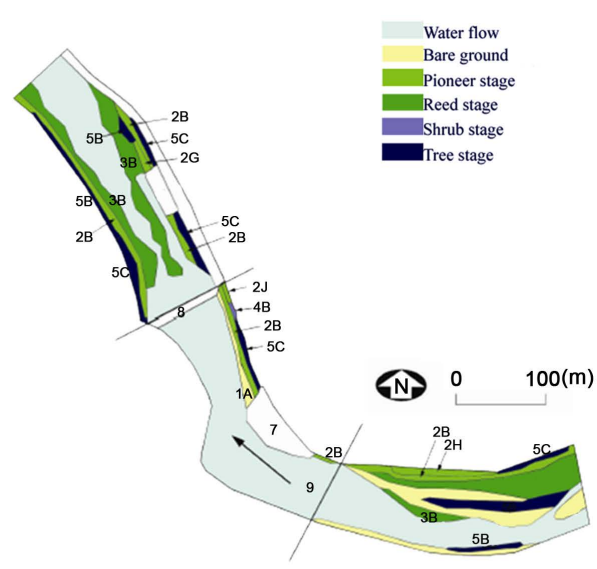

Before removal(March 2006)

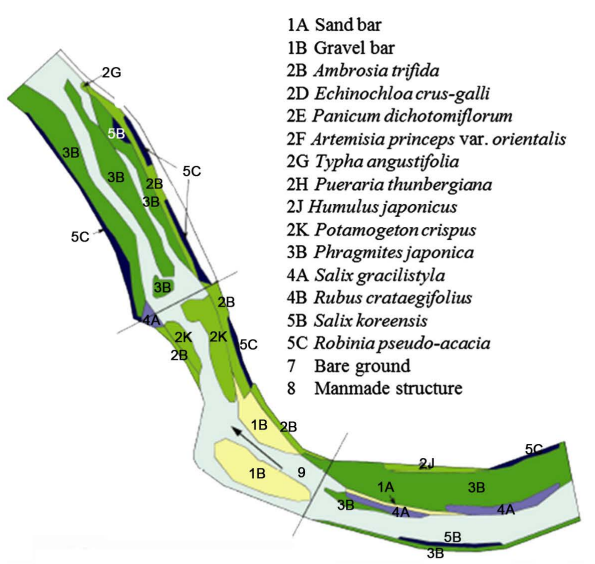

1 year after removal(May 2007)

Figure 4. Monitoring results of riparian vegetation in Gongreung River.

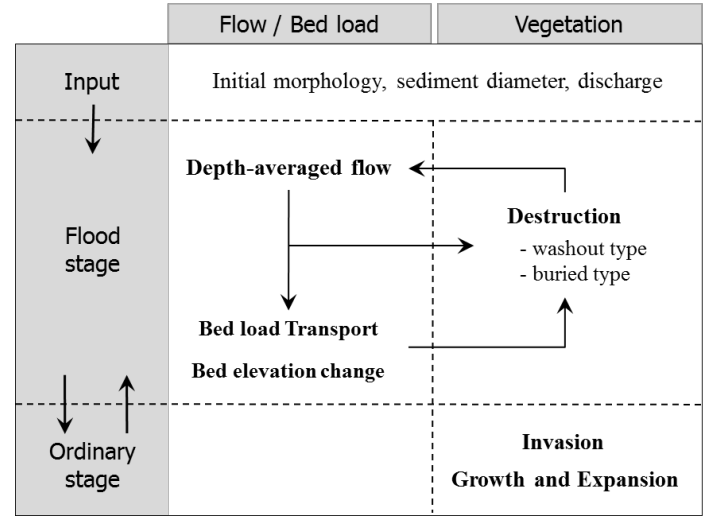

Figure 5. Flowchart of the numerical simulation model.

\subsubsection{Invasion of Riparian Vegetation}

In order to simulate the invasion of riparian vegetation at the interface between water body and the surrounding upland, it is assumed that the vegetation invasion for bare ground takes place in seed dispersal periods, and the seeds are dispersed by flowing water. The invasion possible area is estimated from the differences with ordinary water level and averaged water level of seed dispersal season. The riparian vegetation is settled in the bare ground if the bare ground has not experienced morphological disturbance for $T_{i}$ years. Based on the aerial photograph analysis on Gongreung River, the required time for settlement $T_{i}$ is determined. $T_{g}=1$ year for grass type and $T_{t}=5$ years for tree type, respectively. The initial biomass on the vegetation settlement area is given by:

$$
M_{i}=\frac{z_{0}-z}{z_{0}} M_{i 0}+M_{i 0 \min }
$$

in which $z$ : relative height from the ordinary water stage, $z_{0}$ : relative height of the water level of the seed dispersal season from the ordinary water stage, $M_{i 0}$ : initial biomass at the water edge of the ordinary water stage and $M_{i 0 \min }$ : initial biomass at $z=z_{0}$, respectively (Figure 6).

\subsubsection{Vegetation Destruction}

Regarding the destruction of the riparian vegetation calculated in flood stage, there are the wash out type and the buried type by flood in the numerical model. The wash out type destruction is occurred by the bed scour around the vegetation stand, and the buried type destruction is caused by the sediment deposition around the vegetation stand. The wash out type destruction is occurred either if the local scour depth during flood becomes larger than 


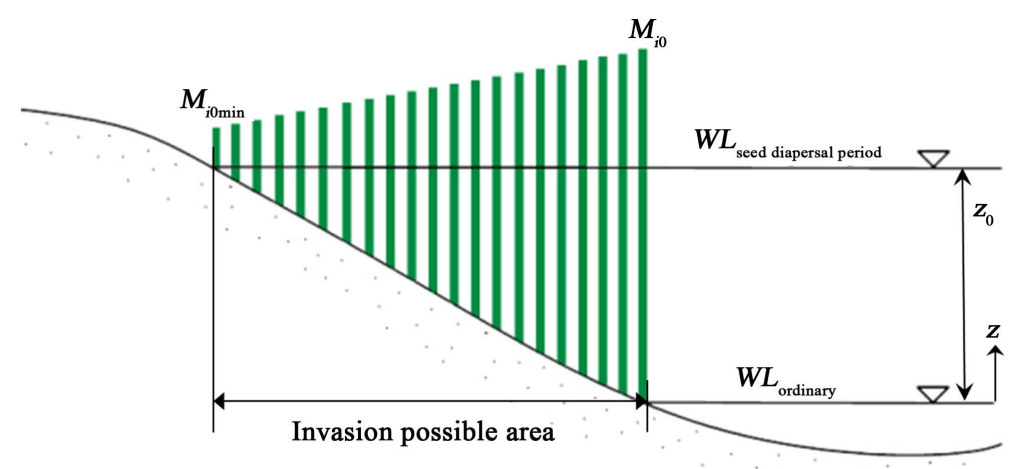

Figure 6. Modeling of vegetation invasion to bare ground.

the root depth or if the bottom friction on the vegetation stand exceeds critical wash out shear stress for vegetation [10] [11]. The buried type destruction takes place when the sediment deposition depth is higher than vegetation height. Also the buried type destruction calculated the vegetation biomass depend on the vegetation height from ground due to the bed elevation changes during flood.

\subsection{Computational Conditions}

A numerical simulation has performed under the conditions of Gongreung River in Korea, in which the average bed slope is 0.00307 and mean diameter of bed material is $0.5 \mathrm{~mm}$. Measured flood discharge data from 2006 to 2010 in Singok observatory have been applied for the calculation of flood stage. Except flood stage, it is assumed that discharge is uniform in ordinary stage. Also, measured data in 2001 for river master plan were applied to create initial morphological data of numerical simulation. Monitoring data of river morphology in May 30, 2006 (just after removal) for adjacent area of the low-head dam were reflected as initial conditions. Table 1 shows the value of vegetation parameters applied for the numerical simulation.

\subsection{Results}

As a result of numerical simulation model, the bed elevation degraded $0.84 \mathrm{~m}$ in the point of previous low-head dam while the river bed elevation aggraded $0.3 \mathrm{~m}$ in $40 \mathrm{~m}$ downstream side from the low-head dam after removal (Figure 7). Monitoring results showed $0.84 \mathrm{~m}$ degradation in the point of previous low-head dam and $0.27 \mathrm{~m}$ aggradation in $39.68 \mathrm{~m}$ downstream side of the dam.

Figure 8 shows the results of numerical simulation model for river morphology and riparian vegetation changes. In upstream of the low-head dam, the numerical simulation results shows that large scale of sand bars have been created with exposing deposited sediment after the low-head dam removal. The newly formed sand bars in upstream side (reservoir) of the low head dam were colonized by grass type plants. Compare to monitoring results, the tree plants were slightly overestimated in numerical simulation model due to the assumption of bare ground. In present numerical simulation, if the bare ground has not experienced morphological experience for 1 year, the grass type plants are settled in the bare ground.

The sand bars in the downstream of the low-head dam developed in both sides of the river banks with new grass type vegetation. In contrast to the upstream results, the results of sand bars and riparian vegetation in numerical simulation were slightly under estimated than monitoring results. For the reason, it is assumed that the limited cross section data caused limitation for simulating detail sand bar formation.

Nevertheless, the numerical simulation model could simulate the general geomorphological changes and riparian vegetation changes following low-head dam removal. According to the results of numerical simulation and monitoring, it was found that the low-head dam removal contribute to form new sand bars and expand the extent of existing sand bars with riparian vegetation colonization. However, the geomorphological changes by the lowhead dam removal was restricted only in vicinity of the low-head dam as the monitoring results denoted that the impacts by a head-cut migration was not significant because of dredging the deposited sediment in the reservoir. In addition, it was simulated that the area of tree type plants is increasing after 5 years later of low-head dam removal. Aerial photo in 2012 (Figure 9) also shows that tree type plants are newly establishing and expanding 


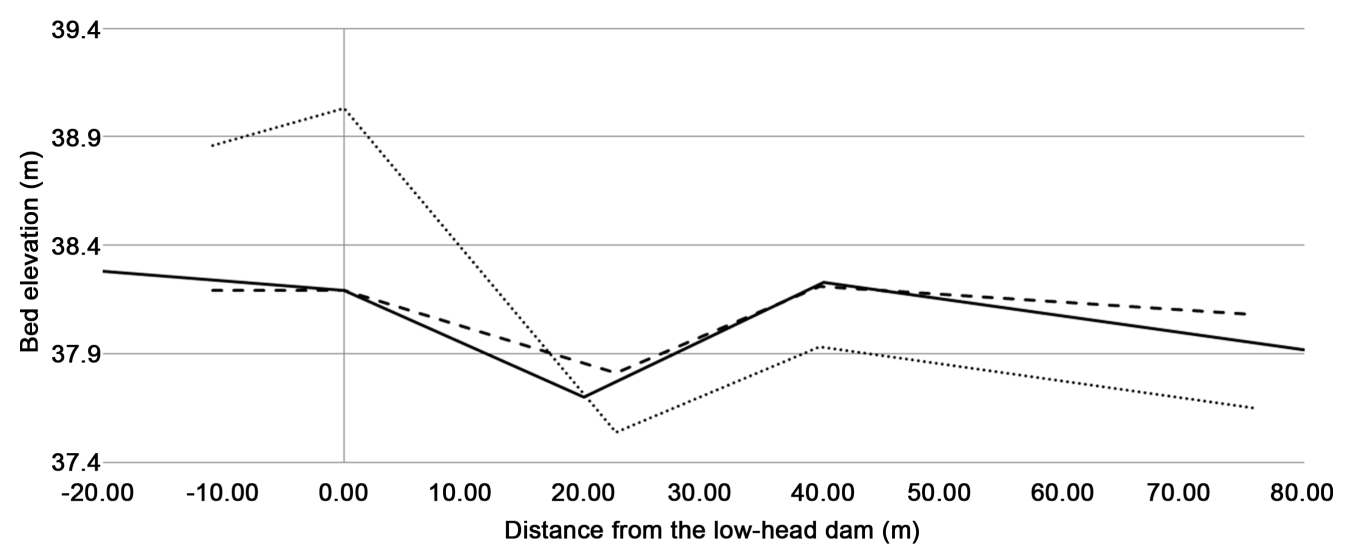

......... Before Removal - -Monitoring - Calculation

Figure 7. Numerical simulation results on river bed elevation changes.
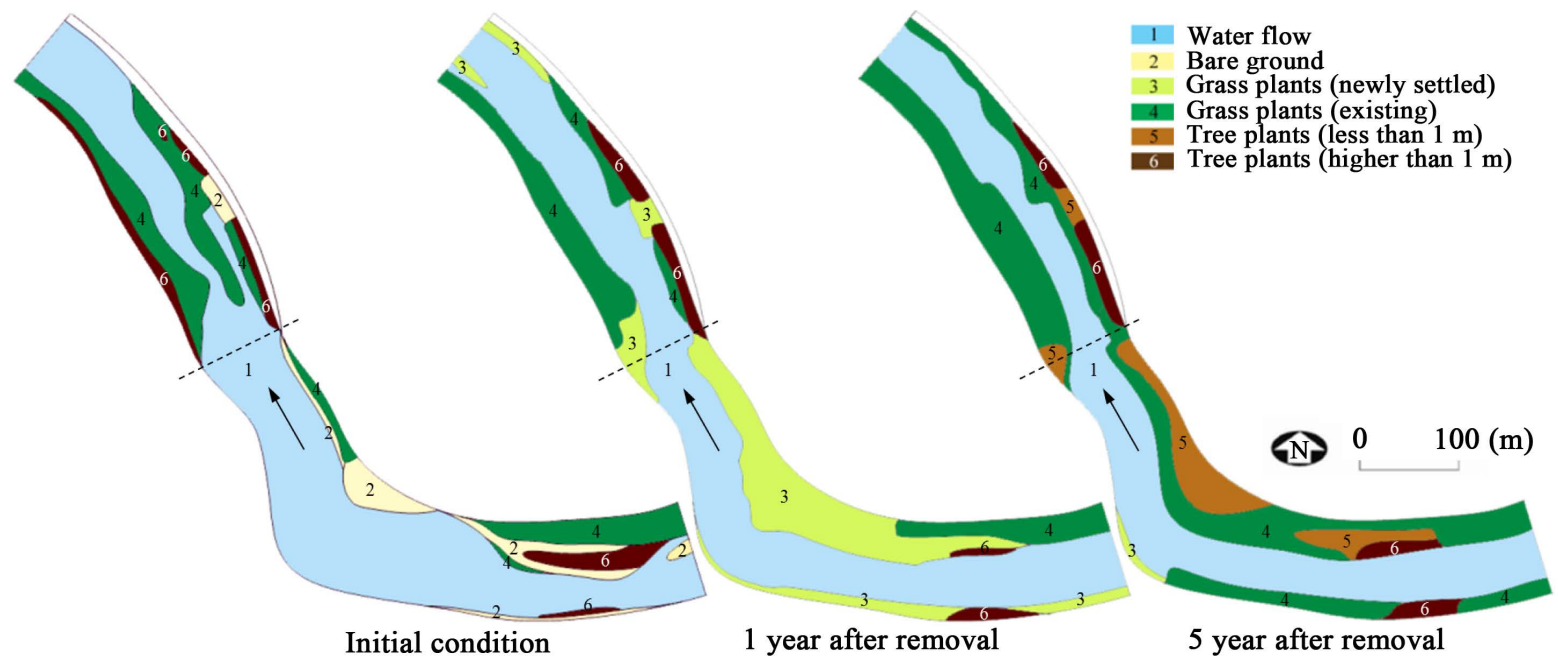

Figure 8. Numerical simulation results on Gongreung River for river morphology and riparian vegetation.

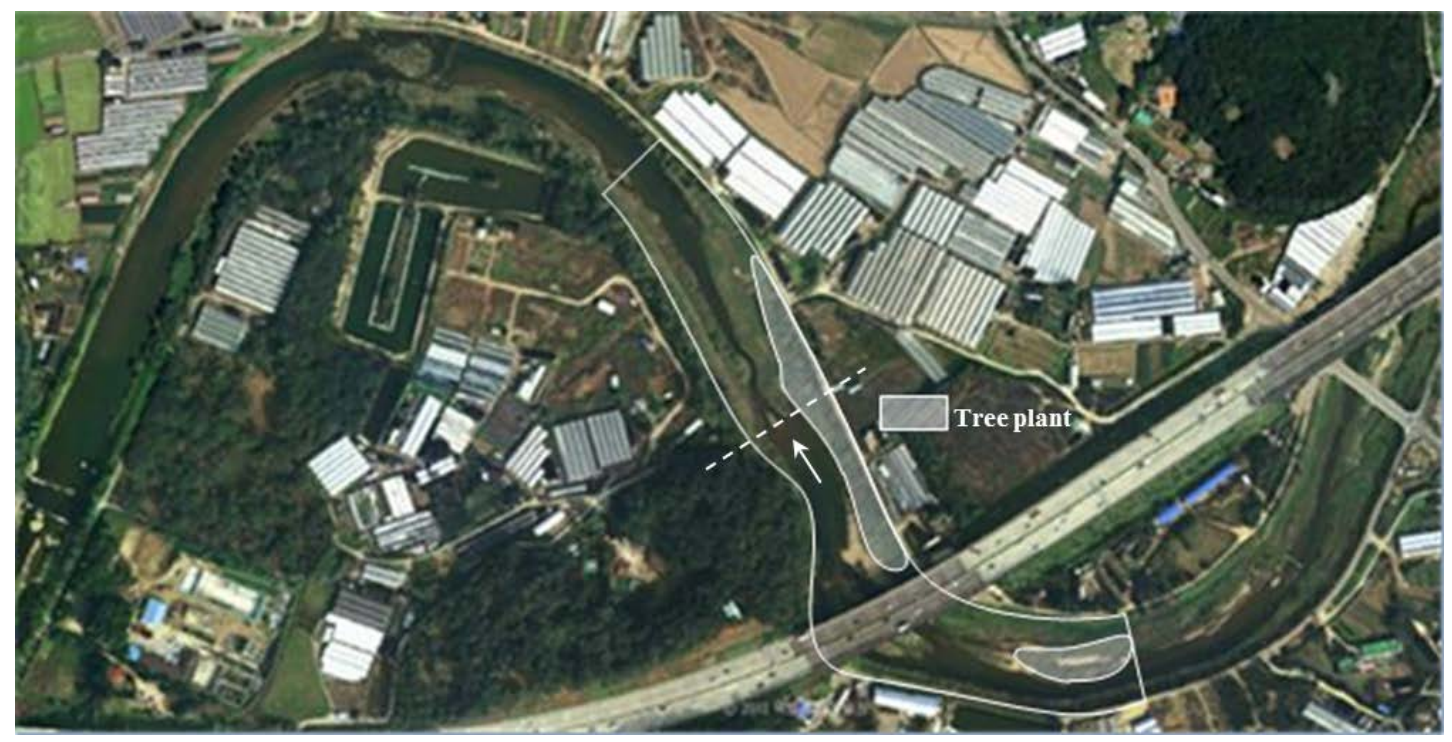

Figure 9. Aerial photo of Gongreung River in 2012. 
Table 1. The value of vegetation parameters.

\begin{tabular}{cccc}
\hline Parameter & Value (grass/tree) & Explanation & Reference \\
\hline$C_{d}$ & 1.0 & Drag coefficient & a. \\
$\chi\left(\mathrm{m}^{-1}\right)$ & 0.02 & Vegetation density parameter & $\mathrm{b}$. \\
$k_{x i}, k_{y i}$ & $4.0 / 2.0$ & Diffusion coefficient for horizontal expansion & $\mathrm{b}$. \\
$M_{i 0 \min }\left(\mathrm{g} / \mathrm{cm}^{3}\right)$ & 6.0 & Minimum initial biomass & $\mathrm{b}$. \\
$M_{i 0}\left(\mathrm{~g} / \mathrm{cm}^{3}\right)$ & 114 & Initial biomass at the water edge & b. \\
$T_{i}$ & $1 / 5$ & Required time for settlement & Measured \\
\hline
\end{tabular}

a. Toda et al. 2005 [12]; b. Toda et al. 2014 [11].

in the river channel. For the effective river management following low-head dam removal, it is necessary to predict long term changes of river morphology and riparian vegetation.

\section{Conclusions}

This study intends to develop the numerical simulation model for analysis of low-head dam removal impacts on river morphology and riparian vegetation. To verify the numerical simulation model, the low-head dam removal case in Gongreung River was applied for the numerical simulation with investigation of low-head dam removal responses on river morphology and riparian vegetation.

The results of monitoring and numerical simulation indicated that there are significant changes on river geomorphology and riparian vegetation following the low-head dam removal. Above all, upstream of the low-head dam has significant morphological changes with exposing deposited sediment. New sand bars have formed by this morphological changes as well as increasing the extent of existing sand bars in upstream of the low-head dam. These sand bars have been mostly colonized in a year after the low-head dam removal by grass type plants. The area of sand bars and riparian vegetation have increased in upstream and downstream of the low-head dam following low-head dam removal.

After a decade to several decades, the riparian vegetation in sand bars often develops to tree type plants in several low-head dam removal cases. As other cases, Gongreung River also showed the growth of tree type plants in 5 years after the removal. Therefore, it is important to study the geomorphological changes with long term riparian vegetation succession following a low-head dam removal for river management as a future study.

\section{References}

[1] Doyle, M.W., Stanley, E.H., Orr, C.H., Selle, A.R., Sethi, S.A. and Harbor, J.M. (2005) Stream Ecosystem Response to Small Dam Removal: Lessons from the Heartland. Geomorphology, 71, 227-244. http://dx.doi.org/10.1016/j.geomorph.2004.04.011

[2] Sawaske, S.R. and Freyberg, D.L. (2012) A Comparison of Past Small Dam Removals in Highly Sediment-Impacted Systems in the US. Geomorphology, 151, 50-58. http://dx.doi.org/10.1016/j.geomorph.2012.01.013

[3] Pizzuto, J. (2002) Effects of Dam Removal on River form and Process. BioScience, 52, 683-691. http://dx.doi.org/10.1641/0006-3568(2002)052[0683:EODROR]2.0.CO;2

[4] Doyle, M.W., Stanley, E.H. and Harbor, J.M. (2003) Channel Adjustments Following Two Dam Removals in Wisconsin. Water Resources Research, 39, 1011. http://dx.doi.org/10.1029/2002WR001714

[5] Shafroth, P.B., Friedman, J.M., Auble, G.T., Scott, M.L. and Braatne, J.H. (2002) Potential Responses of Riparian Vegetation to Dam Removal. BioScience, 52, 703-712. http://dx.doi.org/10.1641/0006-3568(2002)052[0703:PRORVT]2.0.CO;2

[6] Orr, C.H. and Stanley, E.H. (2006) Vegetation Development and Restoration Potential of Drained Reservoirs Following Dam Removal in Wisconsin. River Research and Applications, 22, 281-295. http://dx.doi.org/10.1002/rra.891

[7] Meyer-Peter, E. and Muller, R. (1948) Formulas for Bed Load Transport. Proceedings of 2nd meeting of the International Association for Hydraulic Structures Research, Delft, 7 June 1948, 39-64.

[8] Hasegawa, K. (1981) Bank-Erosion Discharge Based on a Non-Equilibrium Theory. Proceedings of JSCE, 316, 37-52. 
(In Japanese)

[9] Jensen, P.B. (1932) Die Stoffproduktion der Pflanzen. Fischer.

[10] Yagisawa, J., Tanaka, N. (2009) Dynamic Growth Model of River Vegetation Considering the Destruction by Floods and Regeneration Process of Trees. Annual Journal of Hydraulic Engineering, 53, 1171-1176. (In Japanese)

[11] Toda, T., Kim, S.N., Tsujimoto, T. (2014) Relation between Sandbar Mode and Vegetation Expansion in Sand-Bed River. Proceedings of River Flow 2014, Lausanne, 3-5 September 2014, 429.

[12] Toda, Y., Ikeda, S., Kumagai, K., Asano, T. (2005) Effects of Flood Flow on Flood Plain Soil and Riparian Vegetation in a Gravel River. Journal of Hydraulic engineering, 131, 950-960. http://dx.doi.org/10.1061/(ASCE)0733-9429(2005)131:11(950) 
Scientific Research Publishing (SCIRP) is one of the largest Open Access journal publishers. It is currently publishing more than 200 open access, online, peer-reviewed journals covering a wide range of academic disciplines. SCIRP serves the worldwide academic communities and contributes to the progress and application of science with its publication.

Other selected journals from SCIRP are listed as below. Submit your manuscript to us via either submit@scirp.org or Online Submission Portal.
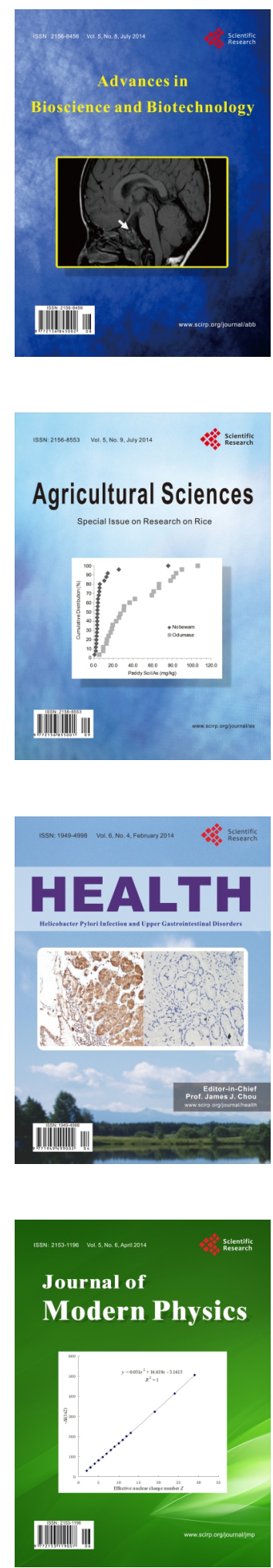
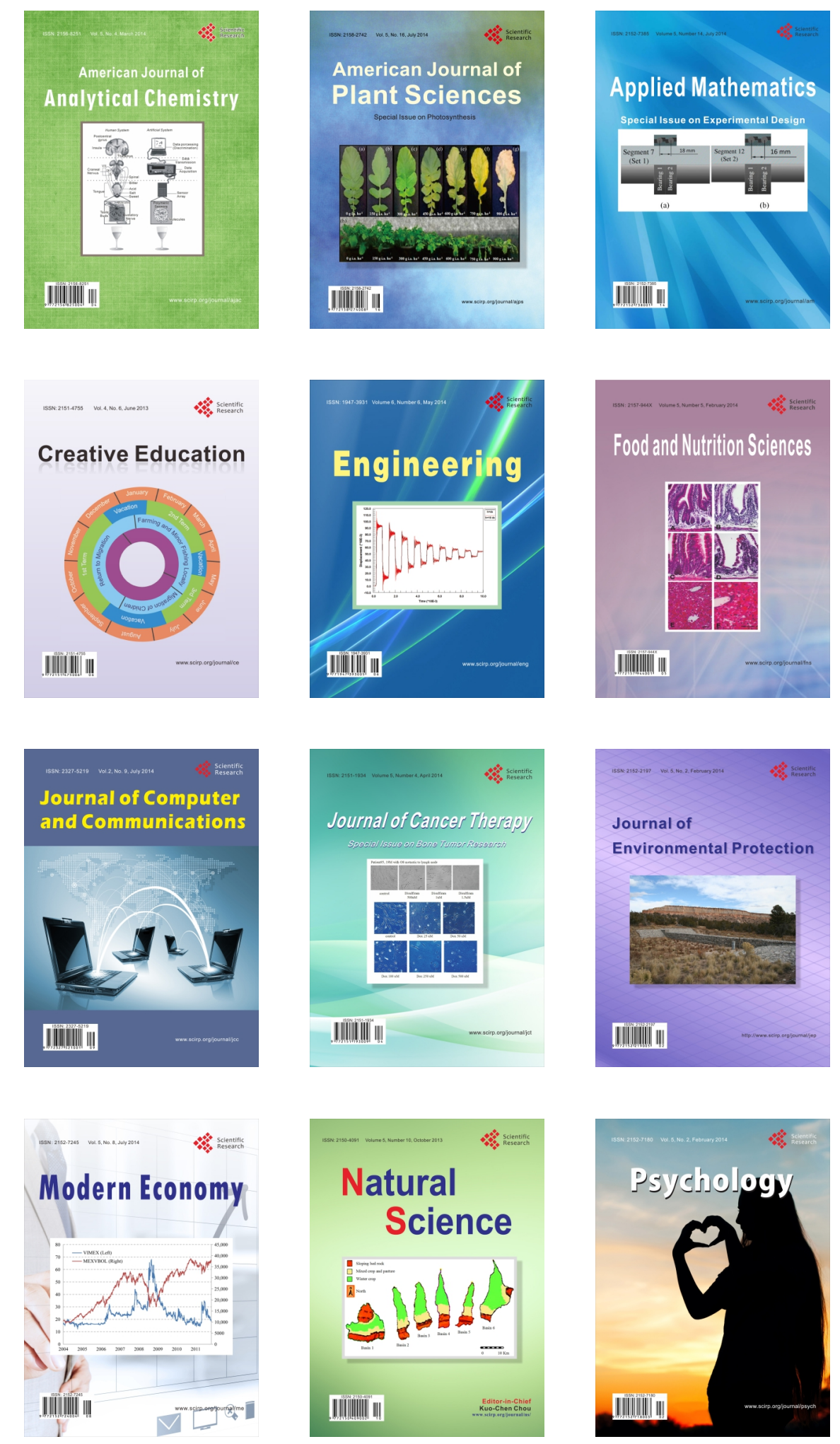